\title{
Exploring Learning Avenues Amidst Pandemic and Future Prospects in Higher Education
}

\author{
Muhammad Shahid \\ Research Scholar, Department of Education, University of Sargodha \\ mshahidbhatti677@gmail.com \\ Muhammad Uzair-ul-Hassan \\ Associate Professor, Department of Education, University of Sargodha \\ uzair.hassan@uos.edu.pk
}

\begin{abstract}
Globally, teaching-learning has been in a severe transition due to COVID-19. Amid pandemic, education in universities had to shift from physical boundaries to online mode. The purpose of the study was to examine online learning mode particularly with respect to learner's readiness, their involvement, fair assessment and satisfaction at university level. The objectives of the study were; to explore the perceived level of readiness of students for online learning, find out their involvement and participation in online mode while performing various educational tasks; to explore to what extent online assessment is fair, and finally to determine satisfaction of students of online learning experiences during COVID-19 era. The sample of the study was drawn from all social sciences departments. The questionnaire's link was disseminated to 550 students and 293 respondents filled out the google form. Learners' readiness was divided into three subfactors, namely, physical \& environmental factors, learners' personal skills and learners' familiarity with necessary apps and websites. The inferences drawn from the study showed that although majority of students were equipped with devices yet they were not possessing good skills required for virtual learning. The online conditions and environment were not contributing positively in favour of learners' readiness and also learners were not well aware of apps \& websites required for online learning. Moreover, students remained passive during online classes and were found less interested in completion of the assigned tasks. The online assessment had been embedded with manifold flaws that further multiplied unfairness in education. Although, the study informs overall satisfaction of learners which found to be low for addressing the issues, it is recommended that educational institutions may continue to offer hybrid mode of learning even in post-pandemic era for continuously equipping both students and teachers with requisite skills, relevant apps and software necessary for making learning teaching process smooth in future. In addition, it is recommended that higher educational institutions and relevant authorities should design software to improve involvement of the students while keeping the assessments as fair as possible during online learning.
\end{abstract}

Keywords: Quality in online Education, Readiness of students, Online Learning, Students' Involvement, Fair Assessment, Satisfaction

\section{Introduction}

Currently the whole world is struggling to fight against the COVID-19 which is caused by severe acute respiratory syndrome coronavirus 2 and this disease is highly infectious (Remuzzi \& Remuzzi, 2020). Because of this situation there is lockdown everywhere and we have no other option left except online learning (Martinez, 2020). During March 2020, the regular 
administrative procedures, teaching and research activities in universities were stopped. This study has examined an overall teaching and learning activities during the era of lockdown. When a sudden shift occurs due to any abnormal situation then obviously it creates lot of problems, now due to pandemic situation the sudden shift has already been occurred and researcher tried to sought out its effect on the situation of education regarding readiness, involvement, fair assessment and satisfaction of students.

Quality of teaching and learning is the great concern of the educationists in whole world. There are several factors which affect the quality of learning. Different educationists determined various categories and dimensions of quality education. According to UNESCO (2004) Readiness of the student is very important indicator of quality learning because if students are not physically, technically and ultimately mentally ready to study then it is sure that the quality of learning will be decreased. Poole (2000) indicated that online courses provide different benefits to the learners such as convenience, while Chizmar \& Walbert (1999) said that online learning is more flexible. Furthermore, he indicated that the prospects to work collaboratively with other students and teachers increased in online learning from different educational institutions even around the world. Here the question arises that either students were ready for online learning or not? Students can only attain these benefits if they are first ready and equipped with the prerequisites for online learning.

Participation or involvement of students during class is also an integral part of learning and second indictor which was under study in this research. Majority of educationists are currently focusing on child centered learning which need an active involvement of the student. Behaviour of the students in the classroom reflect about their learning and seeking knowledge and it may range from active to passive involvement. They may just be seated silently, taking notes, hearing, doing something else, or they may ask questions, giving their opinions, or answering to questions being asked (Yusof, et al 2011; Hussein, 2010;Bas, 2010). The first four things points out a passive behavior while the latter things point out an active type of behaviours in the classroom. Liu (2001) divided student behaviors during class into four categories which are followings: (a) Full integration (b) Participation in the circumstances (c) Marginal interaction, and (d) Silence observation.

Third indicator under study by this research was fair assessment. Assessment is very broad term and it is an integral part of the teaching learning process. According to Lam (1995) "A fair assessment is one in which students are given equitable opportunities to demonstrate what they know". In formal educational setting there was already developed and approved system of assessment by higher education commission of Pakistan and being followed by the universities, but due to sudden change in the mode of learning assessment of students in online learning was one of the major challenges faced by the universities. This study has also examined the level of fairness in assessment during online learning in the eyes of students.

Fourth indicator which was under study in this research is the level of satisfaction of students from online learning experience. Satisfaction of students is also an important factor and a major issue to achieve during online learning (Payne, 2009). According to Merritt (2018) satisfaction of student is an integral part of quality education for retention of student and better achievement as well.

The current situation due to pandemic made an urge for higher education institutions to conduct the various researches related to virtual and online education to achieve the quality education and to get all the stakeholders specifically students satisfied from online learning. 
Hence, this study was highly needed in the current situation of education particularly at university level.

\subsection{Rationale of the study}

Sudden shift of whole academic activities at university level in Pakistan from physical to online mode has put tremendous effect on the education. Either educational institution particularly students were ready for this shift and if they were not ready then what about the quality of education? Currently every person who is associated with education is thinking about the online teaching and learning due to COVID-19 pandemic. Although few institutes in Pakistan were already involved in online learning but remaining all institute and all students around the country were not involved into online education and completely prepared for this sudden shift. Hence, the question arises that in this situation up to which level the quality of education has achieved in online learning. Present study addressed this question and researcher tried to sought out the current position of online education regarding readiness, involvement of students, fair assessment and students' satisfaction along with future possibilities to improve an overall situation of online education.

\subsection{Statement of the Problem}

The present study aimed to check that up to which level teachers and students have attained quality teaching and learning with current practices in online learning particularly in terms of readiness of students, their involvement, fair assessment and satisfaction of university students. Universities in Pakistan have altered the mode of learning from physical to online for teaching and assessment during COVID-19 period. UNESO (2004) declared in a report that quality of education is continuously deteriorating in most of the countries. The current scenario of the world where everyone is stuck into their houses, the urge of online learning is intensively increased, hence the current scenario around the world and particularly in Pakistan has become the stimulus for this study to check out an overall picture of online education during pandemic period against four indicators namely readiness, involvement, fair assessment and satisfaction of university students.

\section{Literature Review}

Around one year from March 2020 to March 2021 there was full, partial or smart lockdown around the globe because of COVID-19. Due to close contact among individuals resulted into millions of deaths. The situation was stated as pandemic because of its harshness and severity. So, the situation was serious and everyone was either willingly or forcefully stuck to their homes. This situation also leads to the closure of educational institutions as well. Because of closure of educational institutions from pre-school to university level, only one option left for us and that was online learning (Martinez, 2020). Hence, all formal educational institutions change the mode of study from physical setting to the online setting, teaching and learning in a classroom to teaching and learning through Zoom or google classroom, from traditional to modern and from seminars to webinars.

Muller, et al (2020) wrote that as the online education is continuously expanding, the institutions are also working to make standards for ensuring quality in online education. It is indicated by Merisotis\& Phipps (2000) that until late 1990s there were no standards, rules or any benchmark available to assure quality in online distance education but during 2000 Institute for higher education policy (IHEP) pin pointed 24 benchmarks for the purpose of quality education in online education which were later on improved or redesigned by Dr. Kaye Shalton by using 
Delphi method in 2010. Dr. Kaye Shalton worked to modify, revise, and improve the various benchmarks and finally he designed a rubric with nine different categories and seventy standards.

Readiness is one of the major dimensions for quality assurance in education. Poulymenakou \& Borotis (2004) defined online readiness as "being physically and mentally ready for specific online learning involvements, actions and experiences," while Choucri et al. (2003) defined online readiness as the capability to get benefitted from the prospects or opportunities that enable the use of e-resources such as Internet.

Herguner, Bugra, Heruner \& Donmez (2020) concluded in his research that learner's readiness has significant relationship with positive learning attitude and readiness becomes a base towards this positive attitude towards learning. Hence, we can say that if learners are not ready then they will not develop a positive attitude towards learning and this will definitely reduce the quality of education. Focus or central aspect of most instruments measuring online learning readiness of students is independent study strategies of learners and technological aspects (Broadbent \& Poon, 2015; Cho\& Heron, 2015; Dray, Marczynski, Lowenthal, Primo. R., \& Miszkiewicz, 2011; Hung, Chou, \& Chen, 2010; Smith, Mahoney \& Murphy, 2003). Now, readiness for learning in an online setting includes some other aspects e.g., development of pedagogical strategies, instructional design, technology affordances for communication, active learning, and collaboration among different online programs (Cheon, Lee, Crooks, \& Song, 2012; Dabbagh, 2007). Overall, we can conclude that every aspect of readiness for online learning have certain important aspects which lead towards achievement of the students and quality of education.

It is one of the key challenges for educational institutions and instructors to get students involved into classroom activities in virtual setting because students are beyond the reach and they can have lot of excuses during virtual environment. Lot of studies has already been conducted related to participation or involvement of students during online learning and majority of them concluded that during online learning students get less involved and during online classes majority of student behave passively rather than active participation (Hrastinski 2007; Romiszowski \& Mason 2004; Vonderwell \& Zachariah 2005).According to Vonderwell \& Zachariah (2005) pinpointed four major factors which also intervene along with some other common factors for students "participation during online learning: (1) Technology and interface characteristics, (2) Student roles and instructional tasks (3) Content area experience (4) Information overload. These factors are needed to be addressed while measuring perceptive or actual participation of students in virtual environment.

Deeley et al., (2019) indicated that at higher level of education in UK student's feedback related to assessment revealed that marking criteria for different assignments are unclear, hence students believe that their grades depend upon luck or teacher's belief rather than on a particular standard or criteria. Furthermore, there is inconsistency in marking of the tests and assignments. Marking patterns or ways are not consistence for every course and every teacher. Similar researches are also conducted in Pakistan and similar results were obtained by the feedback of university students in Pakistan. Instead of fair marking and quality assessment, the assessment in Pakistan is much concerned with memorization and recalling only (Kay, 2008; Barker\& Astray, 2006; Sanders, 2006\&Johnstone, 2003). Computer assisted or web-based online assessment is neither easy to administer nor inexpensive to bear. It requires lot of money to establish and maintain an effective and efficient computer assisted or web-based online assessment system (Drasgow, Luecht, \& Bennett, 2006). Kumar, (2020) conducted research during COVID-19 
pandemic and concluded that a tool is still required to conduct online assessment for controlling ethical issues e.g., plagiarism, cheating etc. According to Ogange, Agak, Okelo \& Kiprotich (2018) for more effective online assessment it is better to conduct continuous formative assessment rather than summative assessment.

Sinclaire (2011, p.4) defined satisfaction as "an enjoyable and a successful experience". The word successful again may be different for different people because everyone's wish to be successful is different. For one student being successful may means to get passing marks but being successful for another student may be getting highest marks in class. So, satisfaction of everyone differ because they expect differently. There are lot of studies available related to satisfaction of students which pinpointed various factors which influence satisfaction of students. Based on Sloan Consortium's quality in online education framework Sinclaire (2011) wrote the six factors which influence satisfaction of students: (1) Faculty (2) Institution (3) Individual student factors (4) Communication factors (5) Course factors and (6) Learning environment factors. According to Ejubović, A., \& Puška, A. (2019) for getting better satisfaction from students during online learning it is important for students to be self-regulated learners. Drennan et. al (2005) also pointed some of the factors necessary for satisfaction of students during online learning which are willingness for this learning mode, technology friendly mindset and abilities to work in virtual environment. Willingness or being ready to learn is first and foremost important factor not only for the satisfaction but also for the motivation of students as well.

\section{Methodology}

Quantitative approach was used in this research. This research was descriptive in nature. A survey was conducted to investigate about the existing situation (Covid $19 \&$ sudden shift to Online learning) and its impact on readiness, involvement, fair assessment and satisfaction of students to present the intensity of the problem.

\subsection{Population and Sampling:}

The population was comprised of all social sciences departments in University of Sargodha. Convenience sampling was used to collect data for the research.

\section{Chart 1: Description of Demographic Data of the participants:}

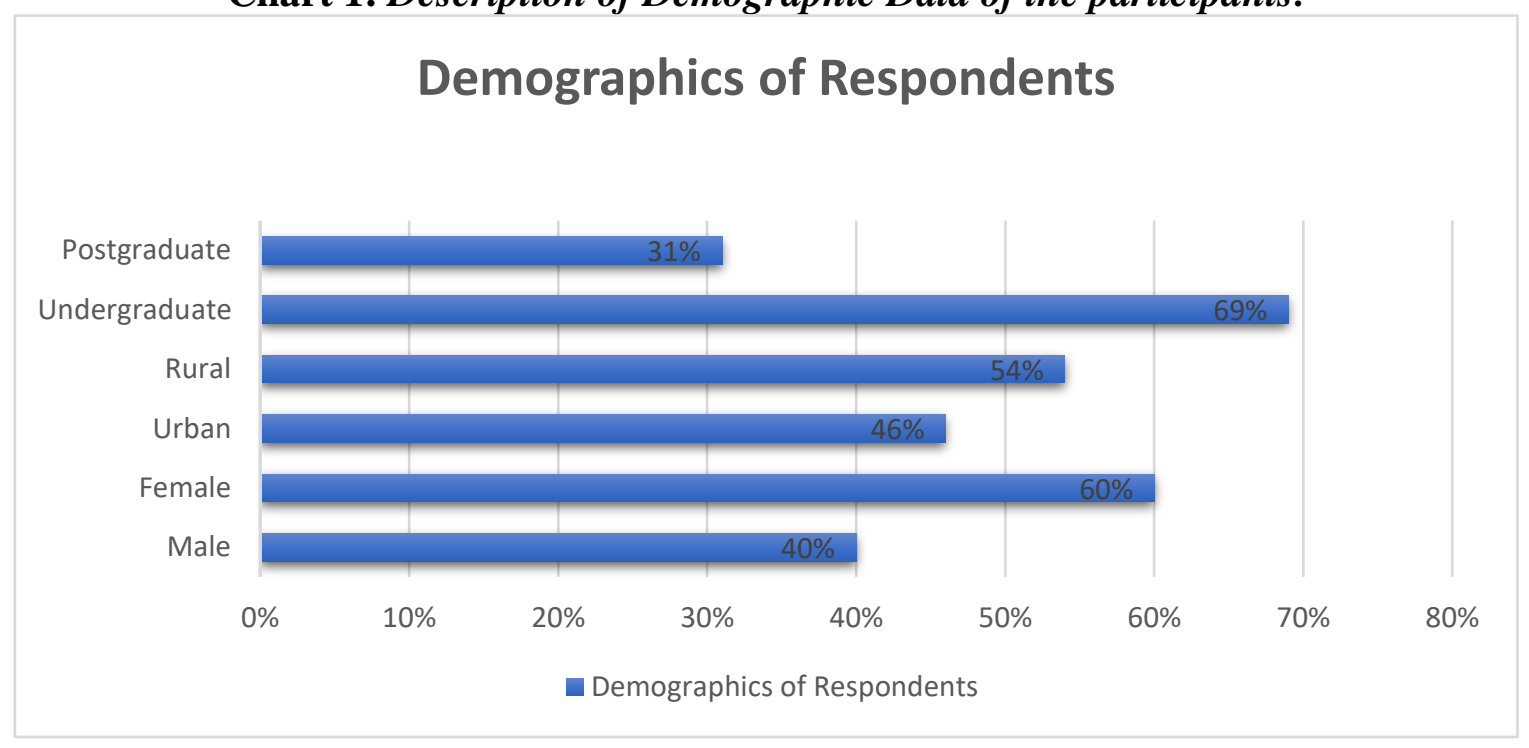


Above chart is showing the details of the demographics of the respondents. Total numbers of respondents were 293. These respondents were studying in five different social science departments which were Education, Economics, Psychology, Business Administration and finally Department of Pak study \& History.

\subsection{Research Instrument}

A Questionnaire was designed and used as the research instrument to gather data about the problem. Questionnaire was comprised of five different parts because there were four different variables under study and part 1 was about the basic or demographic information of the respondents. Part 2 was further having 3 sections and 32 items which were studying readiness of students for online learning as a whole. Section 1 in this part was about Physical and environmental factors, section 2 was about personal skills and section 3 was about usage and familiarity of various websites and apps. Part 3 was about the participation or involvement of the students and comprised of 12 items. Part 4 was about fair assessment during online learning and having 10 items. Part 5 were about satisfaction of students for online learning was which comprised of 11 items.

Researcher also conducted the pilot study of the instrument by collecting data from 25 respondents and analyzed the items. Reliability test was applied. The value of Cronbach's Alpha was 0.86 that showed high reliability of the research instrument.

\section{Analysis of Data}

Chart 2: Physical and Environmental Readiness of students: Sub Factor: Necessary devices for attending online classes:

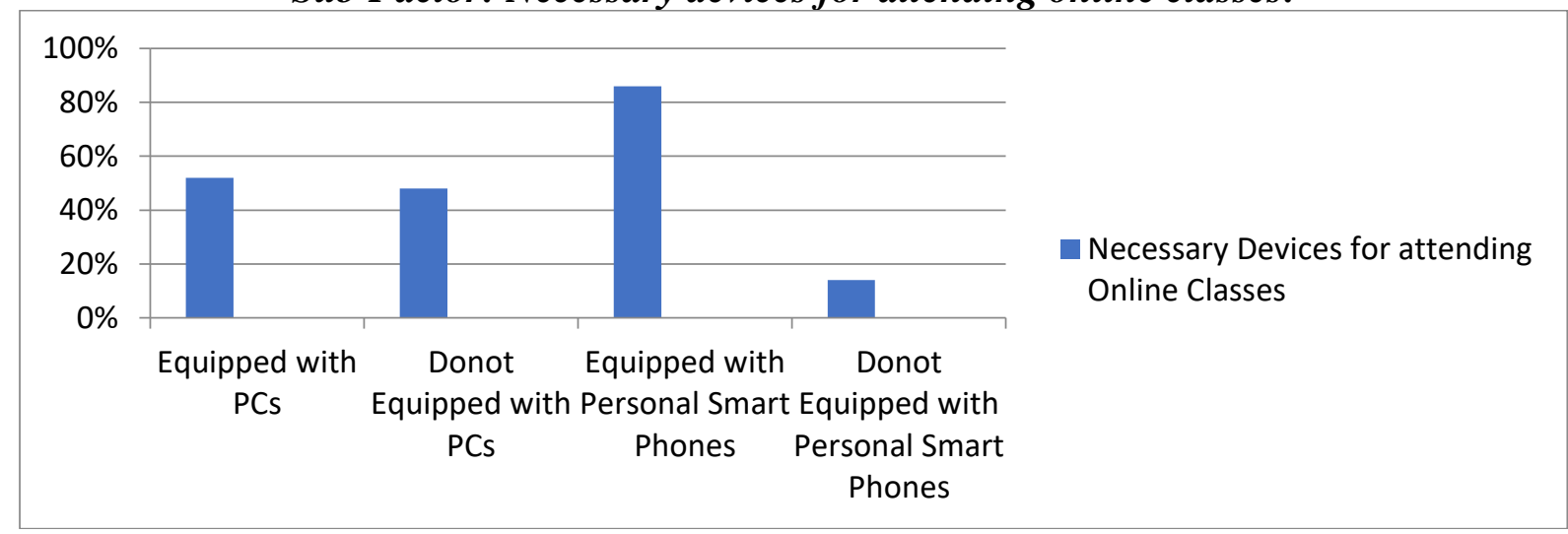

Above Chart is showing that out of 293 respondents 153 (52.2\%) students equipped with personal computers before starting of online classes while 140 (47.8\%) students were not equipped with personal computers. Although large number of students were not having personal computers yet majority of students $253(86.3 \%)$ were equipped with personal smart phones that was alternative to computer devices for attending online classes and only $40(13.7 \%)$ students were not equipped with personal smart phones before starting of online classes. Overall, out of 293 students 278 (94.9\%) students were physically equipped with personal computers or smart phones to attend online classes and only 15 (5.1\%) students were not equipped and have to purchase any device before starting of online classes. 
Table 1: "Quality of devices and environment" for Readiness of students:

\begin{tabular}{|c|c|c|c|c|}
\hline Sr. No. & Variables & Level/Category & $\mathbf{F}(\mathbf{n})$ & Percentage \% \\
\hline 1 & $\begin{array}{l}\text { The quality of your Device (Computer / } \\
\text { Cell Phone for using online apps }\end{array}$ & $\begin{array}{l}\text { Poor } \\
\text { Average } \\
\text { Satisfactory } \\
\text { Good } \\
\text { Very Good }\end{array}$ & $\begin{array}{l}44 \\
98 \\
59 \\
58 \\
34\end{array}$ & $\begin{array}{c}15 \\
33.4 \\
20.1 \\
19.8 \\
11.6\end{array}$ \\
\hline 2 & The quality of internet in your area & $\begin{array}{l}\text { Poor } \\
\text { Average } \\
\text { Satisfactory } \\
\text { Good } \\
\text { Very Good }\end{array}$ & $\begin{array}{l}76 \\
98 \\
49 \\
51 \\
19\end{array}$ & $\begin{array}{c}25.9 \\
33.4 \\
16.7 \\
17.4 \\
6.5\end{array}$ \\
\hline 3 & $\begin{array}{l}\text { Your Home environment was feasible to } \\
\text { attend online classes }\end{array}$ & $\begin{array}{l}\text { Poor } \\
\text { Average } \\
\text { Satisfactory } \\
\text { Good } \\
\text { Very Good }\end{array}$ & $\begin{array}{l}56 \\
76 \\
61 \\
54 \\
46\end{array}$ & $\begin{array}{l}19.1 \\
25.9 \\
20.8 \\
18.4 \\
15.7\end{array}$ \\
\hline 4 & You have availability of internet at home & $\begin{array}{l}\text { Never } \\
\text { Rarely } \\
\text { Usually } \\
\text { Mostly } \\
\text { Always }\end{array}$ & $\begin{array}{l}83 \\
59 \\
51 \\
46 \\
54\end{array}$ & $\begin{array}{l}28.3 \\
20.1 \\
17.4 \\
15.7 \\
18.4\end{array}$ \\
\hline 5 & $\begin{array}{l}\text { You can access internet at somewhere } \\
\text { else only }\end{array}$ & $\begin{array}{l}\text { Never } \\
\text { Rarely } \\
\text { Usually } \\
\text { Mostly } \\
\text { Always }\end{array}$ & $\begin{array}{l}107 \\
75 \\
52 \\
35 \\
24\end{array}$ & $\begin{array}{l}36.5 \\
25.6 \\
17.7 \\
11.9 \\
8.2\end{array}$ \\
\hline 6 & $\begin{array}{l}\text { Did you have separate room to attend } \\
\text { online classes at home }\end{array}$ & $\begin{array}{l}\text { Never } \\
\text { Rarely } \\
\text { Usually } \\
\text { Mostly } \\
\text { Always }\end{array}$ & $\begin{array}{c}126 \\
18 \\
19 \\
21 \\
109\end{array}$ & $\begin{array}{c}43.0 \\
6.1 \\
6.5 \\
7.2 \\
37.2\end{array}$ \\
\hline 7 & $\begin{array}{l}\text { Your home is noisy because of children } \\
\text { or other family members }\end{array}$ & $\begin{array}{l}\text { Never } \\
\text { Rarely } \\
\text { Usually } \\
\text { Mostly } \\
\text { Always }\end{array}$ & $\begin{array}{l}61 \\
47 \\
63 \\
66 \\
56\end{array}$ & $\begin{array}{c}20.8 \\
16 \\
21.5 \\
22.5 \\
19.1\end{array}$ \\
\hline 8 & $\begin{array}{l}\text { Your daily life routine was getting } \\
\text { disturbed due to online classes }\end{array}$ & $\begin{array}{l}\text { Never } \\
\text { Rarely } \\
\text { Usually } \\
\text { Mostly } \\
\text { Always }\end{array}$ & $\begin{array}{l}52 \\
40 \\
44 \\
85 \\
72\end{array}$ & $\begin{array}{l}17.7 \\
13.7 \\
15.0 \\
29.0 \\
24.6\end{array}$ \\
\hline
\end{tabular}




\begin{tabular}{llll}
\hline 9 Did online classes increase your & Never & 87 & 29.7 \\
expenditure? & Rarely & 32 & 10.9 \\
& Usually & 42 & 14.3 \\
& Mostly & 33 & 11.3 \\
& Always & 99 & 33.8 \\
\hline
\end{tabular}

Table 1 has 9 items and each item was measuring physical and environmental readiness of students for online learning. Table 1 is showing the number and percentages of each item against five-point Likert scale.

Table 2: Overall "Physical and Environmental Readiness" of students:

\begin{tabular}{|c|c|c|c|c|c|c|}
\hline \multicolumn{7}{|c|}{$\begin{array}{c}\text { One-Sample Statistics } \\
\text { Test Value }=3.0 \\
\end{array}$} \\
\hline & $\mathbf{N}$ & Mean & Std. Deviation & Sig. & Df & $\mathbf{t}$ \\
\hline Physical and Environmental Readiness & 293 & 2.64 & 0.73 & .000 & 292 & -8.313 \\
\hline
\end{tabular}

Table 2 is showing one sample t test values for physical and environmental readiness as a whole. Researcher was expecting mean value at 3.0 and resultant values indicated that there was significant difference between expected value and actual value. Mean value at 2.64 is less than expected value and it was concluded that although students possess computer or mobile devices yet they were not possessing readiness because various physical and environmental factors were reducing the readiness of students.

Chart 3: Readiness of students against "Personal Skills factors" for online learning Sub factor 1: Required Knowledge \& experience for online learning

\section{Required Knowledge \& Experience for Online}

\section{Learning}

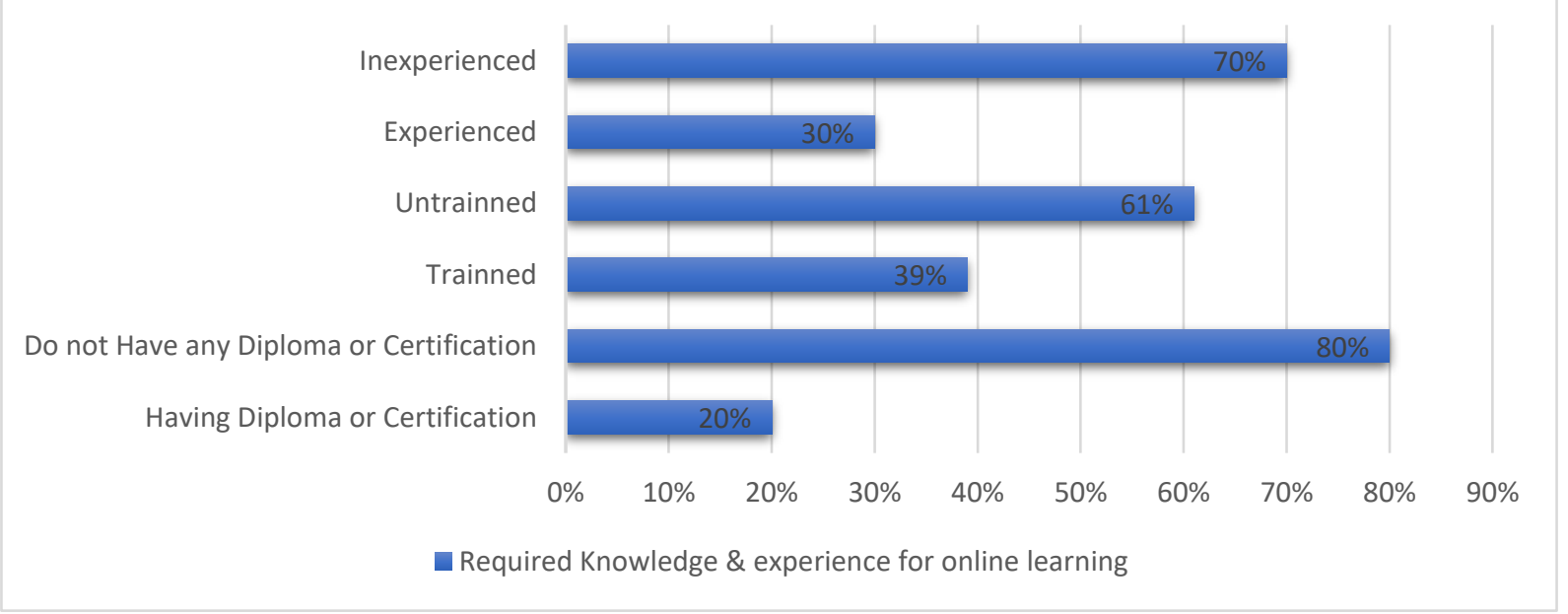

Above graph is showing that out of 293 students only 60 (20\%) students already having any diploma or certificate in computer and rest of $233(80 \%)$ students do not possess any 
diploma or certificate. Furthermore, out of 293 students 114 (39\%) students got training before starting of online classes while $179(61 \%)$ students did not get any training before online classes. As a whole researcher concluded that only $87(30 \%)$ students fulfill the criteria against this subfactor of readiness while remaining $206(70 \%)$ students did not possess readiness for online learning.

Table 3: Skills and Abilities for online learning

\begin{tabular}{lllcc}
\hline Sr. No. & Variables & Level/Category & N & Percentage \% \\
\hline 1 & You Possess good skills to use Apps for & Strongly Disagree & 64 & 21.8 \\
& online learning & Disagree & 84 & 28.7 \\
& & Undecided & 72 & 24.6 \\
& & Agree & 52 & 17.7 \\
& & Strongly Agree & 21 & 7.2 \\
& & & \\
& You have good abilities to operate device & Strongly Disagree & 49 & 16.7 \\
& (computer/ smart Phone) & Disagree & 37 & 12.6 \\
& & Undecided & 11 & 3.8 \\
& & Agree & 130 & 44.4 \\
& & Strongly Agree & 66 & 22.5 \\
3 & You have been engaged in any online & Strongly Disagree & 101 & 34.5 \\
& academic learning before COVID-19 & Disagree & 127 & 43.3 \\
& Undecided & 26 & 8.9 \\
& & Agree & 28 & 9.6 \\
& & Strongly Agree & 11 & 3.8 \\
& & Strongly Disagree & 24 & 8.2 \\
& You already having experience of using & Disagree & 54 & 18.4 \\
& Computer \& Internet & Undecided & 00 & 0.00 \\
& Agree & 162 & 55.3 \\
& & Strongly Agree & 53 & 18.1 \\
\hline
\end{tabular}

Table 3 has 4 items which are related to factor 2 that were personal skills of students for online learning. Table is showing the number and percentages of each subfactors against fivepoint Likert scale.

Table 4: Overall "Personal Skills readiness" for online learning

\begin{tabular}{lccccccc}
\hline \multicolumn{10}{c}{ One-Sample Statistics } \\
\hline & $\mathbf{N}$ & Mean & Std. Deviation & Sig. & df & T \\
Personal skills readiness & 293 & 2.61 & 0.836 & .000 & 292 & -7.948 \\
\hline
\end{tabular}

Table 4 is showing that researcher was expecting the mean value at 3.0 but the resulted mean value was 2.61. There was significant difference between expected and resulted values. Resulted mean value was less than expected mean value. Hence, null hypothesis was rejected and researcher concluded that students did not possess personal skills readiness for online learning. 


\section{Chart 4: "Familiarity and usage of various websites and Apps for Online Learning"}

Familiarity and usage of various websites and Apps for Online Learning

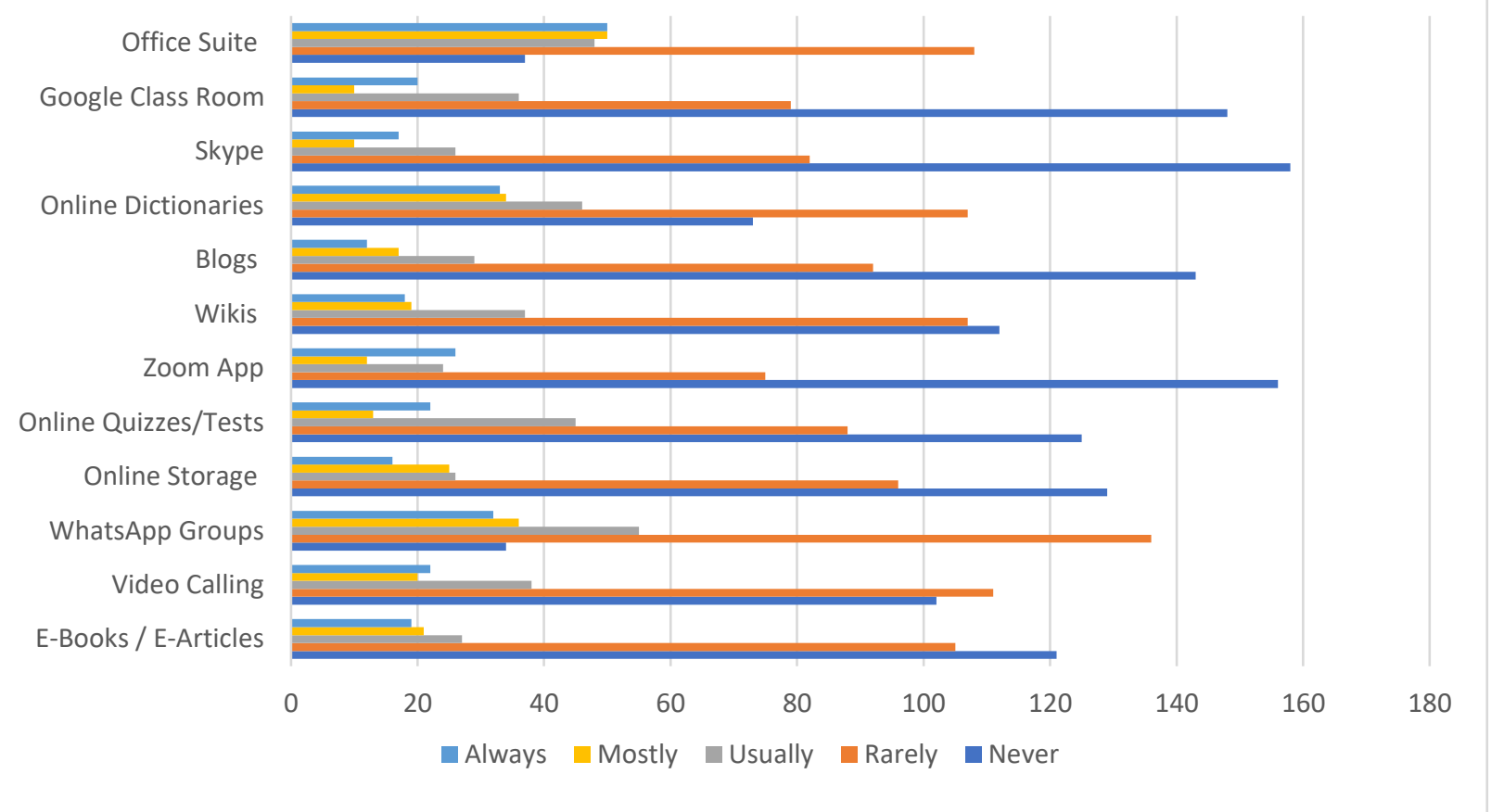

Chart 4is indicating the familiarity and usage of various apps and websites for the purpose of online learning. Majority of students were rarely using most of the apps and websites and they were less familiar with required apps and websites for online learning.

Table 5: Overall Readiness of Students for Online Learning by combining all factors

\section{One-Sample Statistics}

Test Value $=3.0$

\begin{tabular}{lcccccc}
\hline & $\mathbf{N}$ & Mean & Std. Deviation & Sig. & Df & $\mathbf{t}$ \\
Readiness for Online Learning & 292 & 2.46 & 0.55 & .000 & 291 & -16.4 \\
\hline
\end{tabular}

Table 5is showing one sample statistics for overall readiness of students for online learning by combining all factors under study. There was significant difference between expected mean $=3.0$ and resulted mean $=2.46$. Hence, null hypothesis was rejected and it was concluded that students were rarely or less ready for online learning.

Table 6: Perceived level of Involvement or participation of students during online learning

\section{One-Sample Statistics}

Test Value $=3.0$

\begin{tabular}{lcccccc}
\hline & $\mathbf{N}$ & Mean & Std. Deviation & Sig. & df & $\mathbf{T}$ \\
Involvement or participation of students & 293 & 2.19 & 0.42 & .000 & 292 & -32.52 \\
\hline
\end{tabular}


Table 6 indicating one sample $t$ test statistics for involvement of students during online learning. There was total 12 items regarding involvement or participation of students during online classes for educational activities. Researcher was expecting the mean value at 3.0 but unfortunately resulted mean value was less than expected value and that was 2.19. It was concluded that there was significant difference between expected and resulted mean value of students' involvement hence, null hypothesis was rejected. Students 'involvement was less than expected value.

Table 7: Perceived Level of Fair Assessment during Online Learning:

\begin{tabular}{lcccccc}
\hline \multicolumn{1}{c}{ One-Sample Statistics } \\
Test Value $=\mathbf{3 . 0}$ & & & \\
\hline & $\mathbf{N}$ & Mean & Std. Deviation & Sig. & df & $\mathbf{t}$ \\
Level of fair assessment & 268 & 3.20 & 0.58 & .000 & 267 & 5.87 \\
\hline
\end{tabular}

Table 7 showing one sample statistics related to the level of fair assessment during online learning. Researcher was expecting the minimum mean value at 3.0 and resulted mean value was 3.20 which was more than expected value. Hence, there was significant difference between expected value and resulted value. Null hypothesis was rejected and researcher concluded that assessment was usually fair with respect to control of cheating during online learning.

Table 8: Satisfaction level of students during online learning

\begin{tabular}{lcccccc}
\hline \multicolumn{7}{c}{ One-Sample Statistics } \\
Test Value $=\mathbf{3 . 0}$ & & & \\
\hline & $\mathbf{N}$ & Mean & Std. Deviation & Sig. & df & $\mathbf{t}$ \\
Level of satisfaction & 272 & 2.13 & 0.98 & .000 & 271 & -14.46 \\
\hline
\end{tabular}

Table 8 showing one sample statistics of satisfaction level of students during online learning. Researcher has hypothesized the mean value at 3.0 but the resulted value was 2.13 which was less than expected value. There was significant difference between expected value and resulted value. Hence, null hypothesis was rejected and it was concluded that majority of students were rarely satisfied during online learning.

\section{Conclusion \& Discussion}

The study was aimed to find out level of students' readiness due to sudden shift from physical to online mode of education in universities of Pakistan. The results show that although majority of the respondents were possessing various devices for attending online classes yet they were not possessing good skills to attend online classes. Liu, J.C. (2019) concluded in his research that if we take such initiatives in which students 'self-learning skills get improved than this will ultimately result into improvement of readiness for online learning. The results of this study were also suggesting the similar aspects related to readiness of students.

During pandemic situation a study related to readiness of university students was conducted by Chung, Subramaniam \& Dass (2020) in Malaysia and they found that although majority of the students possess readiness yet if they have an option to continue or discontinue online learning then the students will discontinue online learning and prefer to learn physically. Such results show that even if the students possess abilities to learn (readiness) for online learning yet 
mentally, they have not accepted online learning. It is a human nature that they cannot accept and get satisfied from a sudden shift over a night hence, it will take time for the educational institutions to achieve level of satisfaction for the students in digital environment. In the current study researcher also found that environmental situation for online learning was not feasible for majority of the respondents which ultimately results in to dissatisfaction and unwillingness towards online learning.

According to Seman, Hashim, Roslin \& Ishar (2019) the concept of blended learning (combination of online and physical learning) was used in different countries before online learning to improve acceptance and skills of students for online learning and current study also suggesting to educational institutions for taking an initiative to start blended learning at university and colleges level in Pakistan for improving acceptance and readiness for online learning. Social and environmental factor also put significant impact on the readiness of students (Entwistle \& Ramsden, 2015; Horzum, Kaymak, \& Gungoren, 2015). Tomei et al., 2009 wrote that technical abilities are very crucial factors for the students to achieve readiness as well as success in online learning and orientation sessions should also be conducted by the educational institutions on regular basis to improve students 'readiness for online learning. This study also considered these aspects of readiness while measuring it and suggested that students need to have a good environment for higher level of readiness for online learning.

According to McQuirter (2020) the sudden shift of education due to pandemic situation was not willful hence, to make willingness for this change it is necessary to train the students technically and it is required to combine the current practices with new ones for better understanding in the future. The current study also revealed the similar result as majority of the students were not getting involved into educational tasks and they were not satisfied having low level of readiness. Lot of studies revealed that one of the major issues associated with Computer assisted assessment or web-based online assessment is plagiarism and cheating by test takers. Most of the studies found that computer assisted assessment make it easy for the test takers to cheat during testing (Bartley, 2005; Rowe, 2004; Gathuri, Luvanda, Matende \& Kamundi, 2014). The result of current study related to fair assessment also found that assessment was although usually fair yet it needed lot of efforts to make it always fair. Rahul Kumar (2020) also conducted research during COVID-19 pandemic and concluded that a tool is still required to conduct online assessment for controlling ethical issues.

Majority of academic satisfaction studies suggested that teaching methods during online learning needed to match up with students' characteristics to improve the level of satisfaction in virtual environment. Better pedagogical techniques which fit in the virtual environment along with mentally prepared students for online learning will be key towards successful online learning. Blended learning in normal situation can boost up students' characteristics for higher level of satisfaction in the future pandemic situation.

Theory of Reasoned Action (TRA) was adopted by Fred Davis and he proposed the Technology Acceptance Model (TAM). TAM is the significant model in understanding dimensions of human attitude towards rejection or acceptance of the technology. He thought that the definite use of a system is fundamentally a Behaviour or attitude of a person and therefore, the TRA would be appropriate model for enlightenment, prediction and explanation of that behavior (Davis, 1986). Below diagram is showing TAM. 


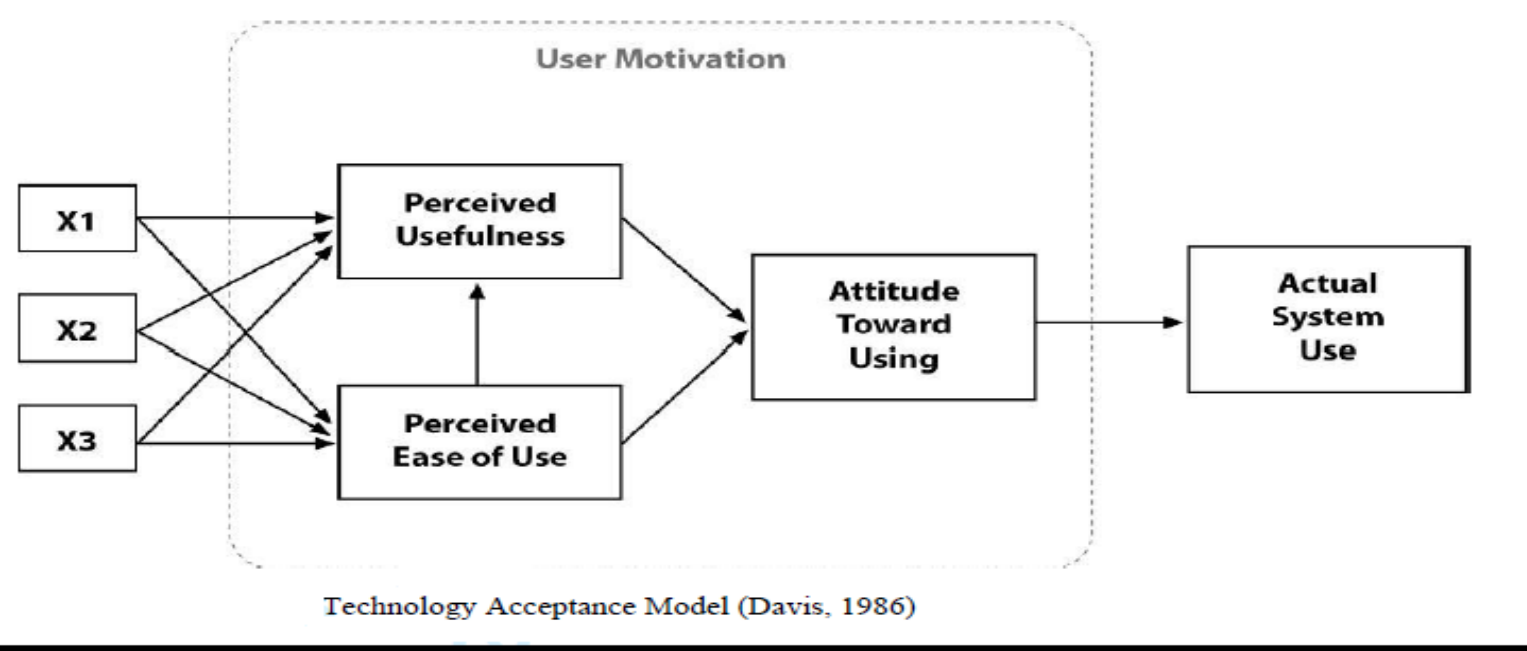

TAM proposed that motivation of an individual have three factors: perceived ease of use, perceived usefulness and attitude toward using. The perceived ease of use is the degree to which the person believes that using any system would be easy for him. Perceived usefulness is the degree to which he/she believes that using any system would enhance her/his performance. Finally, attitude of a user toward the system is considered to be a major determinant of whether the user will actually use or reject the system. The strength of the TAM and its many different versions also called "TAM++" is confirmed by many studies highlighting its broad applicability to various technological contexts. Acceptance of Internet (Lee, Xiong \& Hu, 2012), electronic mail (Serenko, 2008) and online learning (Farahat, 2012) are some of the examples which tested and confirmed the model. Findings of the current study also support TAM. The current emergence of online learning in higher education institutions need lot of improvement to achieve better quality in technology-based learning. This quality will be achieved by considering the above-mentioned factors in TAM and molding the situation in such a way that result into development of attitude of an individual for the acceptance of technology.

\section{Recommendations}

On the basis of above-mentioned findings and conclusions following recommendations were made by the researcher:

It is recommended that:

1. To cope in future with such pandemic situation educational institutions should involve students in training and in such activities which are necessary for online learning to boost readiness of students. For this purpose, educational institutions should offer hybrid mode of learning so that it will become a routine practice for students to attend online classes in the future.

2. Computer and smartphone courses may be indulged into studies with latest online apps and websites so that students got familiar with usage of online apps and websites.

3. Instead of teaching only history of computer students may also be taught the future of computer technology so this will boost the readiness of students for future online learning. 
4. For online live classes instead of using freely available apps which may have some bugs, load problem and limited editions and durations; educational institutions may use their own designed active LMS based software.

5. For better participation or involvement and assessment of student; educational institutions must design a software for online learning with following options:

a. The software should be able to make sure the presence of students during online classes by checking through camera, face detection and fingerprints.

b. The software may have a question bank related to that particular topic which is being taught by the teacher or the teacher may have option to add some questions before delivering a lecture into software so that on a single click by the teacher the software may automatically ask question from a particular student to get him/her involved into studies and make his/her presence more active.

c. Students may also have options to ask questions during online lecture by typing or speaking.

d. Teachers may have options to use various AV aids during lecture by using that software.

e. Software may have a portal to upload and submit assigned tasks by the students with particular deadlines and software may automatically check the plagiarism of submitted assignments.

f. Software must not allow the students to upload any assignment which have more percentage of plagiarism as required by the particular institute or teacher.

g. Software should automatically choose questions from the question bank to assess students' performance on regular basis and suggest him/her for improvement.

h. Instead of only objective or MCQs questions the teacher may have options to assess students 'performance by open ended questions with remote proctoring by using that software.

6. It is also recommended that HEC and other such institutions may train the faculty of educational institution with latest technology-based teaching and learning techniques.

7. Online Open Education Resources may also be integrated in course outlines so that students will be able to boost their autonomous learning skills which will ultimately contribute to improve mental readiness and acceptance for online learning.

\section{References}

Allen, I. E. \& Seaman, J. (2013). Changing course: Ten years of tracking online education in the United States. The Online Learning Consortium. Retrieved from http://onlinelearningconsortium.org/publications/survey/chang ing_course_2012

Ali, A., \& Ahmad, I. (2011). Key Factors for Determining Student Satisfaction in Distance Learning Courses: A Study of Allama Iqbal Open University. Contemporary Educational Technology, 2(2), 118-134. Retrieved from: https://doi.org/10.30935/cedtech/6047

Chizmar, J. F., \& Walbert, M. S. (1999). Web-based learning environments guided by principles of good teaching practice. Journal of Economic Education, 30(3), 248-264.

Chung, E. Subramaniam, G. \& Christ, L. D. (2020), Online Learning Readiness Among University Students in Malaysia Amidst Covid-19. Retrieved from: https://doi.org/10.24191/ajue.v16i2.10294 
Chung, E., Subramaniam, G., \& Dass, L. C. (2020). Online learning readiness among university students in Malaysia amidst COVID-19. Asian Journal of University Education, 16(2), 46-58.

Cheon, J., Lee, S., Crooks, S. M., \& Song, J. (2012). An investigation of mobile learning readiness in higher education based on the theory of planned behavior. Computers \& Education, 59(3), 1054-1064.

Choucri, N., Maugis, V., Madnick, S., Siegel, M., Gillet, S., O’Donnel, S., ... \& Haghseta, F. (2003). Global e-readiness-for what. Center for eBusiness at MIT.

Cho, M. H., \& Heron, M. L. (2015). Self-regulated learning: The role of motivation, emotion, and use of learning strategies in students' learning experiences in a self-paced online mathematics course. Distance Education, 36(1), 80-99.

Dabbagh, N. (2007). The online learner: Characteristics and pedagogical implications. Contemporary Issues in Technology and Teacher Education, 7(3), 217-226.

Dray, B. J., Lowenthal, P. R., Miszkiewicz, M. J., Ruiz-Primo, M. A., \& Marczynski, K. (2011). Developing an instrument to assess student readiness for online learning: A validation study. Distance Education, 32(1), 29-47.

Drennan, J., Kennedy, J. \& Pisarki, A. (2005, July). Factors affecting student attitudes toward flexible online learning in management education. Journal of Educational Research. 331.

Entwistle, N., \& Ramsden, P. (2015). Understanding student learning (routledge revivals). Routledge.

Farahat, T. (2012). Applying the Technology Acceptance Model to Online Learning in the Egyptian Universities. Procedia - Social and Behavioral Sciences, 64, 95-104.

Gathuri, J. W., Luvanda, A., Matende, S., \& Kamundi, S. (2014). Impersonation challenges associated with e-assessment of university students. Journal of Information Engineering and Applications, 4(7), 60-68.

Herguner, G., Bugra, S.S., Heruner, S.S. \& Donmez,A. (2020) The Effect of Online Learning Attitudes of University Students on their Online Learning Readiness

Higher Education Commission (2011) eReforms: PERN, PRR, eLearning, CMS \& Digital Library. Retrieved from http://www.hec.gov.pk/new/ eReforms/eReforms.html.

Hrastinski, S. (2008). The potential of synchronous communication to enhance participation in online discussions: A case study of two e-learning courses. Information \& Management, 45(7), 499-506.

Hussein, G. (2010). The Attitudes of Undergraduate Students towards Motivation and Technology in a Foreign Language Classroom. International Journal of Learning and Teaching, 2 (2) 14-24.

Horzum, M. B., Kaymak, Z. D., \& Gungoren, O. C. (2015). Structural equation modeling towards online learning readiness, academic motivations, and perceived learning. Educational Sciences: Theory and Practice, 15(3), 759-770. 
Kumar, R. (2020) Assessing Higher Education in the COVID-19 Era. A journal of educational $\begin{array}{llllll}\text { research and practice } 2020 \quad \text { Vol. } 29 & \text { (2) 37-41 Retrieved }\end{array}$ from:https://journals.library.brocku.ca/brocked

Lam, T. C. M. (1995). Fairness in performance assessment: ERIC digest, Retrieved from: http://ericae.net/db/edo/ED391982.htm (ERIC Document Reproduction Service No. ED $391982)$

Lee, W., Xiong, L., \& Hu, C. (2012). The effect of Facebook users' arousal and valence on intention to go to the festival: applying an extension of the technology acceptance model. International Journal of Hospitality Management, 31, 819-827.

Liu, J.C. (2019). Evaluating online learning orientation design with a readiness scale. Online Learning, 23(4), 42-61. doi:10.24059/olj. v23i4.2078

Liu, J. C., \& Roberts-Kaye, E. (2016). Preparing online learning readiness with learner-content interaction: Design for scaffolding self-regulated learning. In L. Kyei-Blankson, J. Blankson, E. Ntuli, and C. Agyeman (Eds.), Handbook of research on strategicmanagement of interaction, presence and participation in online courses (pp. 216-243). Hershey, PA: IGI Global.

Martinez, J. (June 22, 2020). Take this pandemic moment to improve education. Edu Source. Retrieved from https://edsource.org/2020/take-this-pandemic-moment-toimproveeducation/633500

Merisotis, J. P., \& Phipps, R. A. (2000). Quality on the line: Benchmarks for success in internetbased distance education. Institute for Higher Education Policy. http://www.ihep.org/Publications/publications-detail.cfm?id=69

Merritt, A.C. (2018) Learning Styles and Demographic Predictors of College Student Satisfaction in an Online Learning Environment

Mosa, A. A., Mahrin, M. N. bin, \& Ibrrahim, R. (2016). Technological aspects of e-learning readiness in higher education: A review of the literature. Computer and InformationScience, 9(1), 113-127.

Muller, K., Scalzo, K.A., Pickett, A.M., Dubuc, L., Dugan, L., McCabe, R., Pelz, W., \& Simiele, D. (2020). Ensuring online learning quality: Perspectives from the State University of New York. Online Learning, 24(2), 254-268. https://doi.org/10.24059/olj.v24i2.2004

Ogange, B.O., Agak, J.O., Okelo, K.O. \& Kiprotich, P. (2018). Student Perceptions of the Effectiveness of Formative Assessment in an Online Learning Environment. DOI: https://doi.org/10.5944/openpraxis.10.1.705

Payne, A., Reza, G., Hamzaee, (2009) An Empirical Analysis of Student Satisfaction Influential Factors in Online Learning

Poole, D. M. (2000). Student participation in a discussion-oriented online course: a case study. Journal of Research on Computing in Education, 33(2), 162-177.

Poulymenakou, A. \& Borotis, S. (2004). E-Learning Readiness Components: Key Issues to Consider Before Adopting e-Learning Interventions. Paper presented at the E-Learn: World Conference on E-Learning in Corporate, Government, Healthcare, and Higher Education 2004, Washington, DC, USA. https://www.learntechlib.org/p/11555 
Remuzzi, A., \& Remuzzi, G. (2020). COVID-19 and Italy: what next? Lancet, 395, 1225-1228. DOI: $10.1016 /$ S0140-6736(20)30627-9

Schulten, K. (2020). Coronavirus resources: Teaching, learning and thinking critically. The New York Times.

Seman, A., Hashim, S.A., Roslin, M., Ishar, R.M. (2019). Millennial Learners' Acceptance and Satisfaction of Blended Learning Environment. Asian Journal of University Education 15(3), 129-141.

Serenko, A. (2008). A model of user adoption of interface agents for email notification. Interacting with Computers, 20, 461-472.

Sinclaire, J. K. (2011). Student satisfaction with online learning: Lessons from organizational behavior. Research in Higher Education Journal. Retrieved from http://www.aabri.com/manuscripts/11825.pdf

Smith, P. J., Murphy, K. L., \& Mahoney, S. E. (2003). Towards identifying factors underlying readiness for online learning: An exploratory study. Distance Education, 24(1), 57-67

Susan J. Deeley, Smith, M.F., Karadzhov, D.\& Koristashevskaya (2019). Exploring the 'wicked' problem of student dissatisfaction with assessment and feedback in higher education, Higher Education Pedagogies, 4:1, 385-405, DOI: 10.1080/23752696.2019.1644659

Tomei, L., Hagel, H., Rineer, A., Mastandrea, L. A., \& Scolon, J. (2009). Do orientation materials help students successfully complete online courses? International Journal of Information and Communication Technology Education (IJICTE), 5(2), 73-89.

UNDP (2020). COVID-19 pandemic: Humanity needs leadership and solidarity to defeat the coronavirus. $\quad$ Retrieved

from https://www.undp.org/content/undp/en/home/coronavirus.html

UNESCO. (2004). Meta survey on the use of technologies in education in Asia and the Pacific on the UNESCO website. Retrieved http://www.unescobkk.org/fileadmin/user_upload/ict/Metasurvey/introduction.pdf

Wei, H.C. \& Chou, C. (2020) Online learning performance and satisfaction: do perceptions and readiness matter? Distance Education, 41:1, 4869, DOI: $10.1080 / 01587919.2020 .1724768$

Yusof, et al. (2011). The Dynamics of Student Participation in Classroom: Observation on level and forms of participation. Paper presented at Learning and Teaching Congress of UKM, 18th-20th. December, Penang, Malaysia.

Yu, T., \& Richardson, J. C. (2015). An exploratory factor analysis and reliability analysis of the Student Online Learning Readiness (SOLR) instrument. Online Learning, 19(5), 120141

Zhoc, K. C. H., \& Chen, G. (2016). Reliability and validity evidence for the Self-Directed Learning Scale (SDLS). Learning and Individual Differences, 49, 245-250.s DOI: http://dx.doi.org/10.1016/j.lindif.2016.06.013 